\title{
Očekávané kompetence studentů oborů aplikované pohybové aktivity a aplikovaná tělesná výchova a jejich rozvoj na základě vstupního předmětu kurz pobytu v letní př́írodě
}

\section{The expected competencies of the student branches of adapted physical activity and adapted physical education and their improving on the base of the course of outdoor summer camp}

\author{
Petra Brusová, Ondřej Ješina \\ Fakulta tělesné kultury, Univerzita Palackého v Olomouci, \\ Česká republika
}

\section{Abstrakt:}

Studijni obory aplikované pohybové aktivity (APA) a aplikovaná tělesná výchova (ATV) jsou vyučovány na FTK UP v Olomouci samostatně se třemi společně orientovanými moduly zaměrenými na pedagogickou (respektive učitelskou) způsobilost, aplikované pohybové aktivity a speciální pedagogiku. Na začátku studia je dle nově akreditovaných studijních oborů zařazen společný letní kurz se zaměrením na seznámení se s budoucím obsahem výuky a rozvojem individuálnich profesnich kompetencí. Do našeho výzkumného šetření, jehož cílem bylo zjistit vybrané předpoklady pro studium, vliv vstupního kurzu na očekávané profesní kompetence, bylo zapojeno 88 osob (53 žen, 35 mužů), věkový průměr byl 23 let (nejmladši 19, nejstarši 50 let). Na základě našich zjištění je nejčastějšim dokončeným vzděláním středoškolské (nepřibuzného oboru). Očekávaným zaměstnáním, které by chtěli na základě studia obou oborů vykonávat, je učitel (nejčastěji se zaměrením na tělesnou výcho- 
vu). Pouze $2 \%$ studentů nemělo v době šetření zkušenosti s prací s osobami se zdravotním postižením (nejčastějši zkušenosti jsme zaznamenali s osobami s tělesným postižením). Z hlediska prínosu vstupního kurzu považuji studenti za nejvýraznější rozvoj kooperativních kompetencí, vysoce hodnotí formování mezilidských vztahů a porozuméní základním př́stupuim při modifikacích programů pro potreby osob se speciálními potřebami.

\section{Abstract:}

Study of adapted physical activity (APA) and adapted physical education (ATV) are taught on the FTK UP Olomouc, together with three individually-oriented modules aimed at teaching ability, adapted physical activity and special pedagogy. Summer course focusing on getting to know the future content of teaching and the development of individual professional qualifications is jointed at the beginning of the study. The aim of the investigation was to determine the prerequisites for study, the influence of the input rate on the expected professional competence were involved 88 people (53 women, 35 men), the average age was 23 years old (the youngest 7 , the eldest 50 years). On the basis of our findings is the most common secondary education completed (an unrelated field). The expected employment, which they would like to study (both discipline) is a teacher (most often with a focus on physical education). Only $2 \%$ of students not in the IP experience working with persons with disabilities (the most common experiences we have with persons with disabilities). In terms of the benefits of the course, students shall be considered as input for easing the development of cooperative skills, highly evaluate the formation of interpersonal relationships and understanding of basic approaches when modifications programs to the needs of persons with special needs.

Klíčová slova: zážitková pedagogika, pedagogické kompetence, profesní předpoklady.

Key words: experiential education, pedagogical competence, professional competence. 
The expected competencies of the student branches of adapted physical activity and adapted physical education... Očekávané kompetence studentů oborů aplikované pohybové aktivity a aplikovaná tělesná výchova a jejich rozvoj...

\section{ÚVOD}

Ačkoliv studijní obory aplikovaná tělesná výchova a aplikované pohybové aktivity existují v ČR již více než 20 (ATV), respektive 5 (APA) let, o kompetencích v oblasti aplikovaných pohybových aktivit (APA) se mluví až $\mathrm{v}$ poslední době. Všeobecně přijímaný rámec kompetencí byl zpracován jako jeden z výstupů projektu EUSAPA - European Standards in Adapted Physical Activities (Kudláček, Morgulec-Adamowicz \& Verellen, 2010). Pro správné pochopení významu APA je potřeba uvést vybrané pilíře dle Válkové (2012), definuje je takto: kontaktní teorie, vnímání ,jinakosti“", kategoriální-nekategoriální pojetí, mobilita jako filozofická kategorie, princip modifikací a princip nezávislého života. Tyto a některé další přístupy jsou zohledněny při plánování a realizaci vstupního kurzu určeného pro studenty oborů ATV a APA od roku 2012. Hlavními úkoly tohoto kurzu jsou zejména:

1) Informativní - poskytnout studentům vstupní informace potřebné pro studium vybraného vysokoškolského oboru.

2) Sociální - seznámení se s kolektivem spolužáků a akademických pracovníků.

3) Vzdělávací - poskytnout základní informace o outdoorových pohybových aktivitách osob se zdravotním postižením. Rozvoj specifických profesních (studijních) kompetencí.

4) Osobnostní - rozvoj některých osobnostních charakteristik.

Ačkoliv je důraz na výše uvedené úkoly vyvážený, v našem šetření jsme se zaměřili zejména na aktivity vzdělávací. Naším cílem tedy byla analýza obsahu předmětu ,Kurz pohybu v letní př́rodě 1 “ a jeho působení na rozvoj subjektivně vnímaných kompetencí studentů aplikovaných pohybových aktivit a aplikovaná tělesná výchova. Na základě takto stanoveného cíle jsme si vydefinovali tyto výzkumné otázky:

VO 1) V jakých oblastech studenti předmětu „kurz pobytu v letní přírodě $1^{\text {“ }}$ vidí největší prrínos pro rozvoj vlastních profesních a osobnostních kompetencí?

VO 2) Jaké je představa studentů oboru APA a ATV o budoucím povolání?

VO 3) Jaké aktivity studenti na předmětu „kurz pobytu v letní př́ŕrodě 1“ vnímali nejpozitivněji? 
VO 4) V jakých oblastech vnímají studenti předmětu „kurz pobytu v letní přírodě 1“ největší př́ínos?

VO 5) Jak jsou studenti spokojeni s dosavadním obsahem jejich studia?

Přičemž výzkumné otázky 3 a 5 jsou doplňkové.

Průcha et al. (2003) definuje klíčové kompetence (podle anglického spojení key competences) jako soubor požadavků na vzdělávání složený z vědomostí, dovedností a schopností použitelných v pracovních i běžných životních situacích. Rozlišuje nadále kompetence učitele a žáka. Cimbálníková (2009) popisuje klíčové kompetence podle tzv. kariérových kotev: technicko-funkční kompetence, manažerské kompetence, jistota, kreativita, autonomie. S ohledem na kompetence v oblasti aplikovaných pohybových aktivit jako kinantropologické disciplíny, kde se prolínají i další vědy o člověku jako pedagogika (zejména speciální pedagogika), sociolologie, psychologie, zdravotnické vědy a řada dalších, jsme se zaměřili na dílčí výsledky projektu European Standard in Adapted Physical Activities (EUSAPA), který byl z podporou Evropské komise řešen na pracovišti katedry APA (FTK UP v Olomouci) v kooperaci s 10 dalšími subjekty EU (Kudláček, Morgulec-Adamowicz \& Verellen, 2010). EUSAPA definuje rámec kompetencí, dovedností a znalostí pracovníků v oblasti aplikované tělesné výchovy, rehabilitace v APA a právě i oblast volnočasových aktivit a sportu. V souladu s tím byl upraven obsah kurzu a na něm realizovaných činností.

\section{METODIKA}

Strategie výzkumného šetření byla svou novostí přístupu heuristická a s ohledem na heterogenní skupiny i komparativní. K vyhodnocení výsledků byl využit smíšený př́stup kvalitativních i kvantitativních přístupů. Využitá metoda byla dotazovací v technikách anketa, vlastní konstrukce a zpětná vazba formou facilitovaných diskusí. Ke zpracování výsledků byl využit standardní software Microsoft Office Excel 2007. Zpětné vazby vzhledem k potřebám výzkumného šetření odhalily zejména libé a nelibé pocity a působení vybraných her a aktivit. Diskuse sloužící jako nástroj zpětné vazby byl nahráván a poté vyhodnocován. 
Ankety vlastní konstrukce byly aplikovány na konci kurzu (anketa I) a na konci prvního semestru studia (anketa II). Anketa I obsahovala 16 uzavřených i otevřených otázek. Byla aplikována na konci kurzu v papírové formě. Anketa II byla aplikovaná na konci semestru v elektronické formě. K vyplnění byli studenti vyzváni osobně a elektronicky e-mailem. Obsahovala 16 uzavřených i otevřených otázek, odlišných než anketa I. V průběhu šetření byli studenti seznámeni s obsahem šetření. $Z$ hlediska etických norem věděli, že mohou z výzkumu kdykoliv odstoupit, účastnili se ho dobrovolně a byli informování o nakládání s daty a o anonymitě výzkumu.

\section{věk účastníků kurzu}

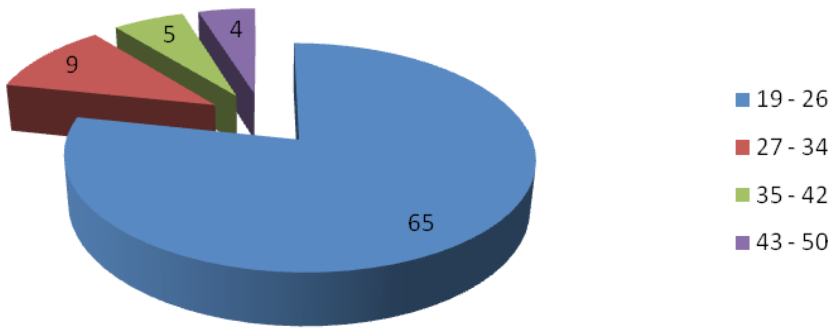

Obr. 1: Věk účastníki̊ kurzu

Do šetření bylo zahrnuto 88 studentů bakalářského studia ATV a APA v prezenční i kombinované formě studia. Jednalo se o 53 žen a 35 mužů, věkový průměr byl 23 let (nejmladší 19 let, nejstarší 50 let). Celkem bylo šetření realizováno na třech kurzech, přičemž první kurz absolvovali studenti dokončující první ročník studia a další dva kurzy nově prííchozí studenti na začátku studia.

Z tab. 1 lze vyčíst, že jedna třetina studentů označila jako nejvyšší dokončené vzdělání střední, 40 \% středoškolské jiného oboru a $13 \%$ středoškolské př́íbuzného oboru. Jako příbuzný obor bylo bráno vzdělá- 
ní tělovýchova, speciální pedagogika, fyzioterapie, sociální péče a vychovatelství, ty oblasti, na které se později během bakalářského studia navazuje. Kurzu se zúčastnilo 8 \% vysokoškolsky vzdělaných studentů, z nichž 3 osoby dostudovaly obor podobného specializace.

Tab. 1: Nejvyšší dokončené vzdělání

\begin{tabular}{|l|l|l|l|l|l|}
\hline nejvyšší dokončené vzdělání & $\mathbf{1 . ~ k u r z}$ & $\mathbf{2 . ~ k u r z}$ & $\mathbf{3 .}$ kurz & celkem & v \% \\
\hline středoškolské & 8 & 10 & 11 & $\mathbf{2 9}$ & $33 \%$ \\
\hline středoškolské jiného oboru & 11 & 7 & 17 & $\mathbf{3 5}$ & $40 \%$ \\
\hline $\begin{array}{l}\text { středoškolské př́buzného } \\
\text { oboru }\end{array}$ & 4 & 3 & 4 & $\mathbf{1 1}$ & $13 \%$ \\
\hline $\begin{array}{l}\text { vyšší odborné jiného oboru } \\
\text { vyšší odborné př́buzného } \\
\text { oboru }\end{array}$ & 3 & 1 & 1 & $\mathbf{2}$ & $2 \%$ \\
\hline $\begin{array}{l}\text { vysokoškolské př́buzného } \\
\text { oboru }\end{array}$ & 1 & 2 & 1 & $\mathbf{4}$ & $5 \%$ \\
\hline vysokoškolské jiného oboru & & 3 & 1 & $\mathbf{4}$ & $5 \%$ \\
\hline & & & & $\mathbf{8 8}$ & $100 \%$ \\
\hline
\end{tabular}

\section{VÝSLEDKY}

Vzhledem k rozsáhlosti výzkumných otázek a omezenému prostoru pro příspěvek uvádíme pouze vybrané výsledky šetření.

Obsah předmětu „kurz pobytu v letní prírodě 1“ byl zaměřen na rozvoj kompetencí studentů nejen kvůli dalšímu působení na škole, ale i v rámci budoucího pracovního uplatnění, které se díky neustále se měnící legislativě pozměňuje. Kompetence, které podle respondentů byly na kurzu největší mírou rozvinuty, lze vidět v následující tab. 2. 
The expected competencies of the student branches of adapted physical activity and adapted physical education... Očekávané kompetence studentů oborů aplikované pohybové aktivity a aplikovaná tělesná výchova a jejich rozvoj...

Tab. 2: Subjektivně vnímané kompetence rozvijené na kurzu $(\mathrm{n}=88)$

\begin{tabular}{|c|c|c|c|c|}
\hline $\begin{array}{l}\text { Kompetence, které byly na kurzu } \\
\text { rozvinuty }\end{array}$ & 1. kurz & 2. kurz & 3. kurz & Celkem \\
\hline spolupráce a soutěžení & 19 & 22 & 19 & 60 \\
\hline schopnost pozitivní motivace okolí & 21 & 17 & 21 & 59 \\
\hline tvorba mezilidských vztahů & 16 & 21 & 20 & 57 \\
\hline $\begin{array}{l}\text { schopnost týkající se vhodné práce se } \\
\text { skupinami }\end{array}$ & 14 & 17 & 22 & 53 \\
\hline zvládá práci v týmu & 14 & 19 & 19 & 52 \\
\hline $\begin{array}{l}\text { rozumět hlavní složkám ovlivňujícím } \\
\text { proces přizpůsobování aktivit }\end{array}$ & 14 & 16 & 20 & 50 \\
\hline rozvoj kreativity & 18 & 14 & 17 & 49 \\
\hline rozumět teorii vytváření programu & 19 & 14 & 15 & 48 \\
\hline dokázat naplánovat odpovídající aktivitu & 14 & 18 & 16 & 48 \\
\hline $\begin{array}{l}\text { mít všeobecný přehled o sportech pro } \\
\text { handicapované }\end{array}$ & 10 & 18 & 18 & 46 \\
\hline $\begin{array}{l}\text { být schopen přizpůsobit aktivity } \\
\text { funkčnímu potenciálu účastníků }\end{array}$ & 11 & 11 & 22 & 44 \\
\hline $\begin{array}{l}\text { rozumět hlavní složkám ovlivňujícím } \\
\text { proces přizpůsobování aktivit }\end{array}$ & 11 & 15 & 17 & 43 \\
\hline rozumět teorii vytváření programu & 20 & 11 & 11 & 42 \\
\hline $\begin{array}{l}\text { dokázat se přizpůsobit prostředí kvůli } \\
\text { zapojení }\end{array}$ & 9 & 16 & 16 & 41 \\
\hline
\end{tabular}

Povědomí studentů o tom, co by mohli v budoucnu po úspěšném absolvování studia vykonávat za pracovní pozice, bylo rozdílné. Nejčetnější odpovědí (u 17 respondentů) byla pozice vychovatele/ pracovníka 
v dětském domově. Více než $10 \%$ respondentů za kompetentní pracovní pozice vypsalo sestupně tyto: učitel, asistent, učitel TV a asistent pedagoga. Odpovědi na to, co by studenti chtěli vykonávat po splnění všech svých studijních požadavků (viz tab. 3), byly rozdílné. Některé byly zcela konkrétní a některé zahrnovaly pouze oblast, ve které by studenti chtěli pracovat. $16 \%$ dotazovaných nemá povědomí o tom, co by chtěli v budoucnu vykonávat za pracovní pozici. $13 \%$ dotazovaných napsalo jako budoucí povolání, které by chtěli vykonávat, učitel. Další místa obsadily pozice jako vychovatel, asistent pedagoga, jakékoliv pracovní místo pracující s osobami s postižením a cvičitel/trenér.

Tab. 3: Pracovní pozice, které by chtěli studenti vykonávat $(\mathrm{n}=88)$

\begin{tabular}{|c|c|c|c|}
\hline pracovní pozice & počet & pracovní pozice & počet \\
\hline nevím & 14 & výživový poradce & 2 \\
\hline učitel & 11 & sociální pracovník v ústavu & 1 \\
\hline vychovatel & 7 & terapeut & 1 \\
\hline asistent pedagoga & 6 & organizátor VČ postižených & 1 \\
\hline práce s osobami s postižením & 6 & práce v centrech & 1 \\
\hline cvičitel, trenér & 5 & logoped & 1 \\
\hline organizátor volnočasových \\
aktivit & 4 & práce v sociálních službách & 1 \\
\hline neuvedl & 4 & asistence při hipoterapii & 1 \\
\hline učitel TV & 4 & výuka lyžování ZP & 1 \\
\hline učitel TV pro ZP, TP, MP, SP & 4 & integrace osob po úrazech & 1 \\
\hline asistent & 4 & pečovatelka & 1 \\
\hline manažer sportovní centra & 4 & OSVČ & 1 \\
\hline osobní asistence & 2 & administrativní pracovník & 1 \\
\hline fyzioterapeut & 2 & voják z povolání & 1 \\
\hline
\end{tabular}


The expected competencies of the student branches of adapted physical activity and adapted physical education... Očekávané kompetence studentů oborů aplikované pohybové aktivity a aplikovaná tělesná výchova a jejich rozvoj...

\begin{tabular}{|c|c|c|c|}
\hline $\begin{array}{c}\text { provozovatel fitness centra, } \\
\text { ředitel }\end{array}$ & 2 & policie ČR & 1 \\
\hline práce v neziskovce & 2 & rehabilitační pracovník & 1 \\
\hline sociální pracovník & 2 & speciální pedagog & 1 \\
\hline
\end{tabular}

Při vyhodnocování samotných aktivit (obr. 2), kdy účastníci mohli zaznačit tři nejoblíbenější, 56 studentů označilo jako nejoblíbenější hru na kurzu Le Mans, paradoxně to pro 35 studentů byla nejtěžší aktivita, což může vypovídat o tom, že tato skupina respondentů má ráda psychicky či fyzicky zaměřené výzvy. Další pomyslnou přičku v oblíbenosti s necelými $50 \%$ hlasů obsadila hra Poseidon, která simulovala plavbu a ztroskotání Titaniku a s 33 hlasy vytvoření a realizace programu v zař́zení pro osoby se specifickými potřebami.

nejoblíbenější aktivity ( $n=88)$

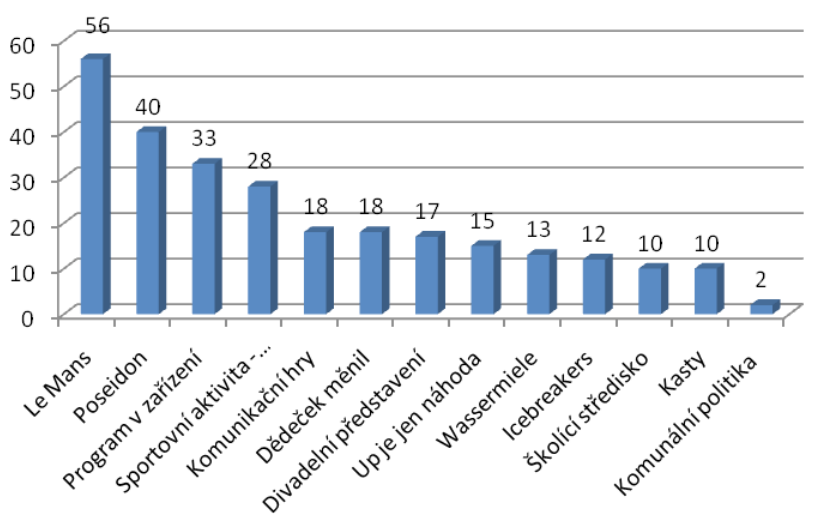

Obr. 2: Nejoblibenější aktivity

Pokud bychom výsledky generalizovali, lze říct, že na prvních dvou místech v oblíbenosti se umístily aktivity simulačního charakteru. Jed- 
na z nich byla zaměřená na fyzickou stránku účastníka a druhá na rychlé a vhodné rozhodování v krizové situaci. Třetí činnost promítala znalosti a zkušenosti studentů do reálné situace v zařízení.

Pro organizátory je velice důležitá zpětná vazba na obsah a samotný prínos kurzu (obr. 3). 85 \% účastníků označilo předmět jako určitě přínosný a nikdo z dotazovaných neohodnotit kurz jako spíše či určitě nepř́nosný. Respondenti se měli možnost vyjádřit $\mathrm{v}$ poslední otevřené otázce, která zkoumala př́nos kurzu a rozvoj jiných kompetencí, které v dotazníku nebyly zmíněny. $V$ obr. 3 jsou přehledně jejich odpovědi zaznamenány.

\section{přínos kurzu}

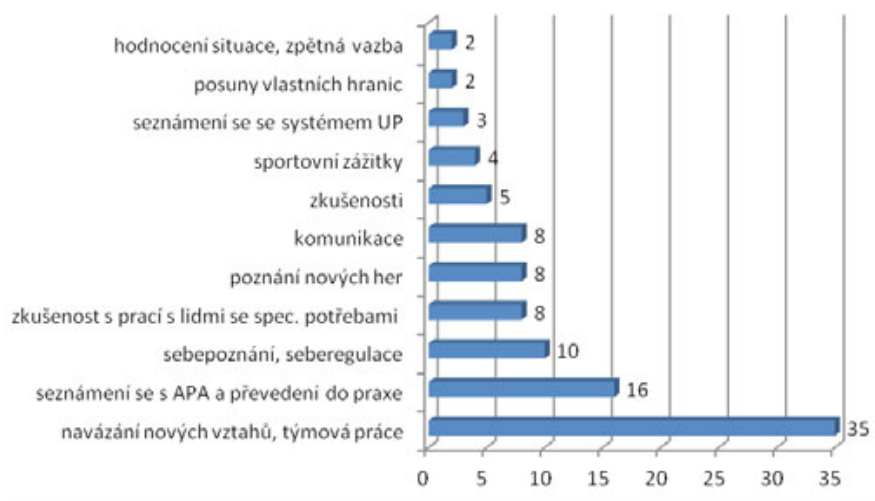

Obr. 3: Př́nos kurzu ihned po kurzu $(n=88)$

Na obr. 4 jsou vyobrazeny 4 strukturované otázky, které byly zaměřeny na př́nos kurzu. Respondenti hodnotili míru prrínosu v oblasti uplatnění se na trhu práce, usnadnění studia, profesní a osobní rozvoj. 75 \% respondentů při hodnocení míry přínosu kurzu označilo jako určitě přínosný obsah kurzu pro usnadnění, prrípadně zefektivnění studia a osobní rozvoj. Kurz byl pro polovinu respondentů určitě př́nosný pro profes- 
ní rozvoj. 17 dotazovaných shledává jako spíše nepřínosný obsah kurzu pro uplatnění se na trhu práce, 15 studentů za určitě př́inosný. Žádný respondent neoznačil kurz jako nepř́nosný pro oblast osobního a profesního rozvoje a usnadnění/zefektivnění studia.

Z hlediska spokojenosti studentů s dosavadním obsahem jejich studia uvedlo 93 \% studentı̊, že studium oborů APA a ATV naplňuje jejich očekávání. Se současným obsahem studia je $93 \%$ studentů určitě nebo spíše spokojeno. $13 \%$ respondentů, kteří studují v kombinované formě studia, jsou spíše nespokojeni s náplní vzdělání (u prezenční formy studia to jsou necelé $4 \%$ ). Pokud bychom srovnávali respondenty podle př́ibuznosti již vystudovaného oboru k oboru aplikované pohybové aktivity, lze vypozorovat, že pro 78 \% studentů, kteří se již vzdělávali v př́ibuzném oboru, určitě splňuje studium jejich dosavadní očekávání (38 \% jiného oboru). Spíše nespokojeni s dosavadním obsahem studia jsou pouze 2 studenti, jejichž předchozí vzdělání bylo středoškolské jiného zaměření.

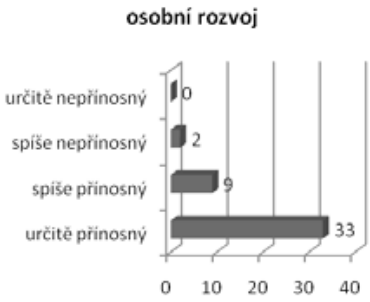

uplatněni na trhu práce

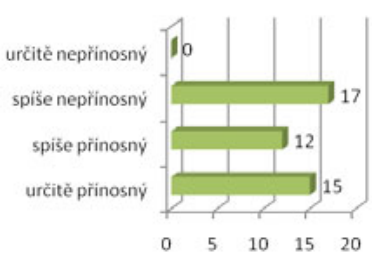

usnadnění/ zefektivněni studia

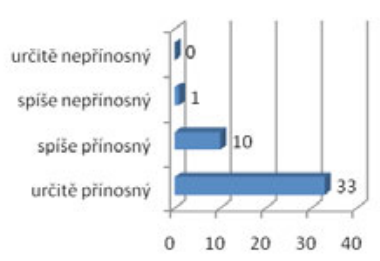

profesni rozvoj

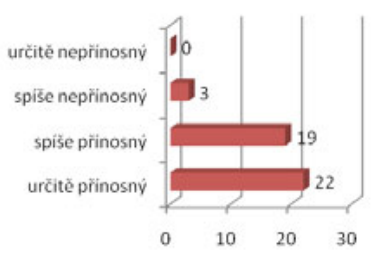

Obr. 4: Míra přinosu předmětu $(\mathrm{n}=44)$ 


\section{ZÁV̌̌R}

Na základě našich zjištění jsme schopni strukturovaně odpovědět na vytyčené výzkumné otázky.

Výzkumná otázka číslo jedna byla definována takto: V jakých oblastech studenti předmětu „kurz pobytu v letní prrírodě 1 “ vidí největší přínos pro rozvoj vlastních profesních a osobnostních kompetencí? $\mathrm{V}$ anketě, která byla poskytnuta bezprostředně po skončení předmětu, respondenti označili za nejrozvinutější kompetence tyto: schopnost pozitivní motivace okolí ( 59 respondentů), schopnost týkající se vhodné práce se skupinami (53) a pochopení teorie vytváření programu (48). Pokud bychom rozebírali hodnocení míry přínosu kurzu v oblasti profesního rozvoje, tak lze generalizovat, že čím jsou studenti vyššího věku, tím menší vidí přínos kurzu právě pro rozvoj v profesní oblasti (odpověd' určitě přínosný označilo necelých $60 \%$ ve věku 19-26 let, $50 \%$ ve věku 27-34 let, pouze $20 \%$ ve věku 35-42 let). Pokud bychom uvažovali o rozdělení studentů na prezenční a kombinovanou formu studia, tak lze určit, že pro respondenty prezenční formy studia byl kurz určitě přínosnější pro profesní rozvoj ( 57 \% a 38 \%). Pokud bychom rozebírali míru př́nosu kurzu ve vztahu $\mathrm{k}$ uplatnění se na trhu práce společně $\mathrm{s}$ předchozím vzděláním studentů, z výsledků anket je patrné, že vyšší procento středoškolsky či vysokoškolsky vzdělaných studentů př́ibuzného oboru shledává předmět pro uplatnění se na trhu práce jako určitě př́nosný (50 \% a 25 \%). Všichni vysokoškolsky vzdělaní studenti zhodnotili jako určitě př́nosný předmět pro osobní rozvoj (100\%).

Výzkumná otázka číslo dvě byla vymezena takto: Jaká je představa studentů oboru APA a ATV o budoucím povolání? Názory na možnou profesní profilaci byly rozdílné. Ve větší míře byly obecnější u studentů denní formy studia, studenti kombinované formy, kteří v anketě také uváděli své stávající zaměstnání, většinou chtějí po absolvování studia vykonávat podobnou, ale díky vzdělání specializovanou pozici (např́klad učitel - učitel ve speciální škole). Z odpovědí respondentů na otázky týkající se chtěné pracovní pozice lze vyvodit, že studenti si v následujícím semestru studia po skončení kurzu uvědomili, jakou pozici by chtěli 
The expected competencies of the student branches of adapted physical activity and adapted physical education...

Očekávané kompetence studentů oborů aplikované pohybové aktivity a aplikovaná tělesná výchova a jejich rozvoj...

vykonávat (v první anketě $21 \%$ respondentů odpovědělo nevím a v následující pouze $14 \%$ ) a lokalizovali svou profilaci (v první anketě uvedl trenér, ve druhé již trenér osob s tělesným postižením). Nejčetnější odpovědí na otázku týkající se povolání, které by studenti po úspěšném absolvování studia chtěli vykonávat, byla učitelská profese (učitel, učitel TV, učitel TV ve speciální škole), v první anketě tuto pracovní pozici uvedlo $22 \%$, ve druhé $21 \%$ respondentů.

Výzkumná otázka číslo tři byla stanovena takto: Jaké aktivity studenti na předmětu „kurz pobytu v letní př́rodě 1“ vnímali nejpozitivněji? Za nejoblíbenější aktivitu v anketě bezprostředně po skončení kurzu ženy označily hru Le Mans, u 30 \% mužů to byla hra Poseidon. Více než $20 \%$ respondenti̊ ve věku 19-26 let vnímalo nejpozitivněji hry Le Mans a Poseidon. V ostatních věkových kategoriích byl za nejoblíbenější aktivitu určen nácvik a realizace programu v zařízení. $Z$ tohoto lze vyvodit, že studenti do 26 let se přiklánějí k simulačním hrám, studenti vyššího věku dávají přednost činnostem, ve kterých mohou aplikovat své teoretické zkušenosti do praxe. Větší procento studentů, kteří absolvovali stř̌ední či vysokoškolské vzdělání příbuzného oboru, jako nejoblíbenější aktivitu určili program v zařízení (61 \% a 36\%). V anketě, která následovala po dalším semestru studia, byla otázka zaměřena na užitečnost daných aktivit. Za nejužitečnější aktivitu ženy označily program v zařízení, u mužů to byly hry Poseidon a Le Mans. Pokud budeme přihlížet ke spokojenosti respondentů s dosavadním studiem a jeho obsahem a budeme tento faktor srovnávat s užitečností daných aktivit na kurzu, více než 20 \% studentů, kteří jsou s obsahem spíše nebo určitě spokojeni, označili jako nejúčinnější aktivitu program v zařízení, což bylo pro některé první seznámení s klienty se specifickými potřebami. Žádný student, který je s obsahem studia spíše nespokojen, neoznačil právě tuto aktivitu jako nejužitečnější.

Výzkumná otázka číslo čtyři byla definována následovně: V jakých oblastech vnímají studenti předmětu ,kurz pobytu v letní přírodě $1 “$ největší př́nos? Všichni studenti považují kurz za přínosný, z toho 100 \% studentů, kteří uvedli jako nejvyšší dokončení vzdělání vysokoškolské, 
dokonce jako určitě přínosný. Studenti vnímají největší přínos kurzu v navázání nových kontaktů, seznámení se s APA a převedení do praxe, rozvoj sebepoznání a seberegulace, nové zkušenosti s prací s lidmi se specifickými potřebami, poznání nových her a v rozvoji komunikace.

Výzkumná otázka číslo pět je tato: Jak jsou studenti spokojeni s dosavadním obsahem jejich studia? Tato výzkumná otázka byla do mé diplomové práce zařazena $\mathrm{z}$ toho důvodu, že kurz byl součástí obsahu studia, a tudíž mohl názor do jisté míry ovlivnit. $93 \%$ studentů uvedlo, že studium oborů APA a ATV naplňuje jejich očekávání. Se současným obsahem studia je 93 \% studentů určitě nebo spíše spokojeno. $13 \%$ respondentů, kteří studují v kombinované formě studia, jsou spíše nespokojeni s náplní vzdělání (u prezenční formy studia to jsou necelé $4 \%$ ). Pokud bychom srovnávali respondenty podle prŕibuznosti již vystudovaného oboru k oboru aplikované pohybové aktivity, lze vypozorovat, že pro $78 \%$ studentů, kteří se již vzdělávali v příbuzném oboru, určitě splňuje studium jejich dosavadní očekávání (38 \% jiného oboru). Spíše nespokojeni s dosavadním obsahem studia jsou pouze 2 studenti, jejichž předchozí vzdělání bylo středoškolské jiného zaměření. 


\section{LITERATURA}

Cimbálníková, L. (2009). Manažerské dovednosti I.: Vybrané manažerské dovednosti +50 manažerských cvičení a testů. Olomouc: Univerzita Palackého.

Kudláček, Morgulec-Adamowicz, \& Verellen. (2010) EUSAPA: European Standards in Adapted Physical Activities. Olomouc: UP v Olomouci.

Průcha, J., Walterová, E., \& Mareš, J. (2003). Pedagogické slovník. Praha: Portál.

Válková, H. (2012). Teorie aplikovaných pohybových aktivit pro užití v praxi 1. Olomouc: Univerzita Palackého.

\section{KONTAKT:}

Bc. Petra Brusová, brusova.petra@seznam.cz 